\title{
Are Asset Securitizations Sales or Loans?
}

\section{Wayne R. Landsman, ${ }^{1}$ Ken Peasnell, ${ }^{2}$ Catherine Shakespeare ${ }^{3}$}

July 2006

1. Kenan-Flagler Business School, University of North Carolina at Chapel Hill, Chapel Hill, NC 27599.

2. The Management School, Lancaster University, Lancaster, LA1 4YX, UK.

3. Steven M. Ross School of Business, University of Michigan, Ann Arbor, MI 48109

We thank workshop participants at Cambridge University, the 2006 European Accounting Association Congress, the University of Cyprus, UCLA, and University of Southern California for helpful comments. We acknowledge funding from the KPMG research fund at the University of North Carolina. Corresponding author: Wayne Landsman, Kenan-Flagler Business School, University of North Carolina, Chapel Hill, NC 27599-3490, 919-962-3221, wayne landsman@unc.edu. 


\title{
Are Asset Securitizations Sales or Loans?
}

\begin{abstract}
This study addresses whether asset securitizations are really asset sales or a form of secured borrowing, by estimating cross-sectional equity valuation regressions to assess whether the stock market treats securitized assets and liabilities held by a special purpose entity (SPE) as assets and liabilities of the sponsor-originator (S-O). Overall, we find that the market views the SPE assets and liabilities as belonging to the S-O, i.e., the risk and rewards of ownership of the transferred assets reside with the S-O and not the SPE. Results from a boot-strapping simulation that controls for scale by randomly assigning SPE assets and liabilities from one S-O to another provide evidence that scale bias is an unlikely explanation for finding the market views SPE assets and liabilities as belonging to the S-O. Findings from specifications in which we permit coefficients to differ for S-O firms with high and low relative levels of retained interest indicate that whereas the market views asset securitizations by low retained interest S-O firms as sales, i.e., risk transfer has taken place, it views asset securitizations by high retained interest S-O firms as secured borrowings, i.e., risk transfer is incomplete. We also show that although the market views securitizations by regulated and unregulated S-Os as secured borrowing, there is suggestive evidence that regulated firms have greater incentives to use securitizations to achieve off-balance sheet financing.
\end{abstract}




\section{Introduction}

Asset securitizations have become a large source of corporate financing. By the end of the third quarter of 2003 , the asset securitization market was valued at $\$ 6.8$ trillion, making it second in size only to U.S. treasuries, which were valued at \$7.1 trillion (Bond Market Association, 2004). Asset securitizations enable a firm to obtain cash for assets transferred to another entity. In a typical securitization, the so-called sponsor-originator (S-O) sets up a special purpose entity (SPE), which borrows funds from a third party to purchase the securitized assets from the S-O. The SPE's borrowing is usually at an investment grade rate because the S-O guarantees in some form some or all of the debt issued by the SPE. If various conditions (described below) are met, the S-O removes the securitized asset from its balance sheet and records a sale. The collapse of Enron, a frequent user (and abuser) of securitizations, focused the attention of securities regulators, accounting standard setters, and the media on whether accounting recognition and disclosure requirements for securitizations were adequate for investors to understand the economic costs and benefits of the securitization transaction on the SO. In particular, a key question is whether asset securitizations are really asset sales or a form of secured borrowing. ${ }^{1}$

In response to the Enron accounting crisis, a Congressional committee asked the Securities and Exchange Commission (SEC) to prepare a report to address accounting issues relating to off-balance sheet activities (SEC, 2005). Although by Congressional mandate the report focuses on asset securitizations and special purpose entities, the SEC report broadens the scope to include a number of transactions that receive degrees of off-balance sheet treatment, including pensions and leases. The key issue relating to these transactions are indeed similar to

\footnotetext{
${ }^{1}$ Bond rating agencies, including Moody's Investors Service (2002) have expressed concern that accounting for asset securitizations that permit sale accounting treatment results in financial statements that present a misleading picture of the credit strength of companies.
} 
those relating to asset securitizations, in particular whether risks and rewards of ownership have been transferred from the firm to its employees and retirees (pensions) or to a lessee (leases). The pension question has been studied by Landsman (1986), employing a research design we adapt to our present study.

The primary research question we address is whether the stock market treats securitized assets and liabilities held by an SPE as assets and liabilities of the S-O. We do so by estimating cross-sectional equity valuation models for a sample of 297 S-O firm-year observations representing 112 firms that disclose securitization information in their financial statements in 2000-2004. The key valuation model is one that includes measures of the S-O's assets and liabilities, estimates of the SPE's assets and liabilities, and S-O income. This analysis requires us to restate the S-O's assets, liabilities, and income as if no sale had taken place, i.e., as if the SPE's operating activities are consolidated with those of the S-O. If the market views the SPE as a truly separate entity, then its assets and liabilities will not be priced in such a valuation equation. If the converse is true, the SPE assets and liabilities will be priced as if they belong to the S-O. We find that the market views the SPE assets and liabilities as belonging to the S-O, i.e., the risk and rewards of ownership of the transferred assets reside with the S-O and not the SPE. To ensure our results are not an artifact of scale, we conduct a boot-strapping simulation that controls for scale by randomly assigning size-adjusted SPE assets and liabilities from one S$\mathrm{O}$ to another. Evidence from the simulations suggests that scale bias is an unlikely explanation for finding the market views SPE assets and liabilities as belonging to the S-O.

A second research question we address is whether the amount of "retained interest" arising from its securitization transactions affects the market's perception of the degree to which risk has been transferred to the SPE. Retained interest is a common means by which bankruptcy 
of the SPE is made a remote prospect, and it therefore serves the function of a guarantee. Consistent with predictions we develop, we find that the market views securitization transactions by S-O firms with relatively high and low amounts of retained interest differently. In particular, whereas the market views asset securitizations by low retained interest $\mathrm{S}-\mathrm{O}$ firms as sales, i.e., risk transfer has taken place, it views asset securitizations by high retained interest S-O firms as secured borrowings, i.e., risk transfer is incomplete.

We also find that although the market views securitizations by regulated and unregulated S-Os as secured borrowing, there is suggestive evidence that regulated firms have greater incentives to use securitizations to achieve off-balance sheet financing.

Our study adds to the small, growing body of research examining accounting issues relating to asset securitizations. Dechow, Myers, and Shakespeare (2004) and Shakespeare (2004) address questions regarding whether managers engage in asset securitizations partly to manage reported earnings. A study more closely related to ours by Nui and Richardson (2004) shows that off-balance sheet debt related to asset securitizations has the same risk relevance as recognized debt for explaining market measures of risk (i.e., CAPM beta). Our study complements Nui and Richardson (2004) by showing the market values SPE debt similarly to recognized S-O debt. However, our study provides a more comprehensive picture by showing that SPE assets also are valued by the market similarly to recognized S-O assets.

To motivate our study, we begin by developing an economic theory of why firms use securitizations in lieu of other forms of debt financing. The principle conclusion from this analysis is that securitizations enable firms to mitigate bankruptcy costs associated with other forms of direct borrowing. We also show that regulated financial firms have additional costs that are mitigated by achieving off-balance status for their borrowings. 
The remainder of the paper proceeds as follows. Section 2 provides background information concerning asset securitization, including a description of the salient institutional features and the accounting requirements. Section 3 discusses the economic theory of asset securitizations, which is the basis for our empirical tests that are described in section 4. Section 5 describes our data and sample and how we consolidate the SPE and S-O to create accounting amounts needed for our estimations and tests. Section 6 presents the findings, and section 7 presents a summary and concluding remarks.

\section{Background}

In a typical securitization transaction, an $\mathrm{S}-\mathrm{O}$ transfers a cash flow stream generated by a pool of financial assets such as mortgages, loans, and leases to an SPE. The SPE finances the transfer by borrowing from financial institutions and other outside investors. These lenders are repaid by the SPE from the cash flows generated by the securitized financial assets. The S-O usually retains a portion of the pool of securitized financial assets, which is commonly referred to as the retained interest. If certain conditions described below are met, then the transfer of assets from the S-O to the SPE can be treated as a "sale" by the S-O for accounting purposes. In addition, if additional conditions are met, then the SPE's balance sheet is not consolidated with that of the S-O, permitting the S-O to achieve off-balance sheet financing.

The rules governing accounting for asset securitizations in the US are provided in Statement of Financial Accounting Standards No. 140 (FASB, 2000; hereafter SFAS 140).

SFAS 140 requires the firm to record the transaction as a sale if the S-O meets certain conditions relating to whether it is deemed to have relinquished control over the assets. First, the S-O unequivocally transfers legal title to the assets to the SPE, i.e., the assets have been isolated from the S-O in the case of bankruptcy. Second, SFAS 140 does not allow the S-O to enter an explicit 
agreement to buy back non-performing assets. ${ }^{2}$ Third, the SPE must be free to pledge or exchange the assets. If these and other sale accounting treatment conditions are met, the S-O removes the securitized assets from its balance sheet and recognizes a gain or loss on the sale.

A related issue is whether the SPE's activities must be consolidated with those of the SO. During our sample period, the US accounting rules governing this issue were comprised of conditions stated in paragraph 35 of SFAS 140 and a series of pronouncements from the Emerging Issues Task Force (EITF) and views expressed by key SEC staff. These guidelines include a requirement that the SPE finance the transfer by issuing equity equal to at least $3 \%$ of the value of the total claims. If this and other requirements were not met, then the S-O was required to consolidate the SPE. This, of course, would effectively undo the sale accounting and bring back the transferred assets and the associated debt issued by the SPE onto the consolidated balance sheet.

Prior to SFAS No. 140, few companies provided details on their securitizations. After the issuance of SFAS 140, effective January 2000, S-Os are required to disclose separately, among other details, the total principal amount of financial assets that the S-O manages that have previously been securitized and continues to be involved with, gains from securitizations during the year, and the book value of any retained interests.

In the period following the collapse of Enron, in the US the Financial Accounting Standards Board (FASB) issued guidelines for implementing SFAS 140, including Financial Interpretation No. 46 (Revised), Consolidation of Variable Interest Entities (FASB, 2003; hereafter FIN 46R). FIN 46R focuses on more formally codifying the rules defining effective

\footnotetext{
${ }^{2}$ SFAS 140 does allow S-O firms to repurchase certain assets through either calls or removal of account provisions (paragraphs 51-54 and 85-88). However, the repurchase ability is extremely limited. If the provisions give the S-O effective control over the transferred assets, then sale accounting is disallowed.
} 
control that were previously covered by SEC and EITF pronouncements. ${ }^{3}$ Presently, the FASB and the International Accounting Standards Board are together deliberating changes to financial reporting requirements for accounting for asset securitizations. The data used in the present study are unaffected by these ongoing developments.

\section{Theoretical Analysis}

To answer the accounting question of when it is appropriate for accounting purposes to treat a securitization as a sale and when it should viewed as secured borrowing it is necessary to examine the motives for securitization. Securitization is a form of financial intermediation. As with many issues in financial economics, it is useful to start from the perspective of a MillerModigliani (M\&M) world in which firms can borrow and lend without incurring transaction costs or costs associated with financial default. In such a setting, firms with complex debt structures created to tap different debt clienteles would simply be shifting risks from one class of debt-holder to another. At the margin, financial transactions would create no value for the stockholders. In a costless M\&M world, the only value created by debt financing is that it can reduce the firm's tax obligations. Aside from potential tax benefits, it is unclear how securitization adds value, particularly as the overall effect of the transactions tends to accelerate rather than delay the recognition of income. However, it is even less clear in an M\&M world why the accounting treatment should have any economic consequences.

Moving away from the M\&M world, the demand for securitization stems from two sources. One is to provide a means of using a portfolio of risky assets to support the issuance of debt to institutions and other investors who require the securities they hold to be of investment grade, i.e., to meet the market's demand for relatively low risk debt. The other, more subtle,

\footnotetext{
${ }^{3}$ However, there is an explicit exception for securitization transactions, in which SPE is considered a qualifying SPE under SFAS 140.
} 
reason can be traced to the possibility that bankruptcy costs caused by attempts by debtholders to upset predetermined priorities in bankruptcy. In the US, Chapter 11 of the bankruptcy code certainly makes this possible. Securitization is a means to lower both costs. How these objectives can be met can be understood by briefly considering the securitization process.

As noted above, the S-O typically sets up an SPE that purchases part of the S-O's assets, or even undertakes originating transactions itself, and finances these transactions by issuing asset-backed debt instruments. The portfolio of assets to be used as security for the SPE's debts must be transferred from the S-O to the SPE in such a way that the courts will accept that a "true sale" has taken place in the event of the bankruptcy of the S-O. ${ }^{4}$ A true sale creates a fire wall between the claims of debtholders in the S-O and debtholders in the SPE by making it difficult for the S-O's debtholders to seek recourse to the assets transferred to the SPE. ${ }^{5}$ The fire wall is the means of assuring the debtholders of the SPE that their claims will not be diluted by the claims of the S-O's debtholders. ${ }^{6}$ The creation of such a fire wall is straightforward if the assets are exchanged for cash on a non-recourse basis: the portfolio of transferred risky assets will have been replaced by cash, leaving the S-O's debtholders with no reasonable grounds for complaint (assuming the transaction is at fair value).

The complication arises that the securitization must be done in a way that makes bankruptcy of the SPE a remote prospect. ${ }^{7}$ As already noted, one reason for securitization is for the S-O to issue investment grade securities by protecting the SPE's debtholders from dilution

\footnotetext{
${ }^{4}$ To achieve this in practice, the S-O obtains a true sale opinion from a lawyer stating that the SPE is bankruptremote from the S-O.

${ }^{5}$ There does not appear to be any case law directly addressing whether a contested securitization transaction is a true sale or a secured financing. The Chapter 11 bankruptcy of LTV Steel appears to be the first occasion in which a securitization structure has been unwound by the court and the decision subsequently challenged by an SPE creditor. For further details, see Stark (2002).

${ }^{6}$ Hansmann, Kraakman, and Squire (2006) arrives at the more general insight that the corporation exists as a business structure not only to limit the liability of stockholders, but also to protect the claims of the corporation's debtholders from being diluted by claimants of the stockholders' personal creditors.

${ }^{7}$ For further analysis of how this might be achieved, see Gorton and Souleles (2004).
} 
from the S-O's other creditors. An additional reason for setting up a bankruptcy-remote vehicle is that it will nearly always be the case that the transferred assets will be used as collateral for issuing different tranches of debt to suit the differing asset portfolio needs of investors. ${ }^{8}$ The different tranches will have different priorities of claims, with the attendant possibility of costly legal proceedings in the event of default. ${ }^{9}$ The SPE must therefore be set up in a manner that minimizes the possibility of such disputes. This can be done in a variety of ways. One way is to over-collateralize the debt of the SPE. Over-collateralization is equivalent to substituting equity for debt financing, with the attendant cost of foregone tax shields. Another is to offer some form of guarantee, either explicit or implicit. However, when offering a guarantee, it is critical not to put the sale at risk of being deemed a loan by the courts; otherwise, the securitization would also be at risk. ${ }^{10}$ True sale status of the asset transfer will not be jeopardized by a loan guarantee that is provided by a genuine third party. More typically, the S-O provides the bulk of the credit enhancements. ${ }^{11}$ This can take the form of the S-O providing the SPE with standby letters of credit. However, because standby letters of credit work only to smooth out fluctuations in the SPE's cash flows, it can at best only be a partial solution to the risk borne by the SPE's creditors. A particularly important and common form of credit enhancement is for the S-O to purchase the most junior securities issued. These junior securities are often referred to as the equity tranche, or the "toxic waste". This retained interest acts as a guarantee in the sense that

\footnotetext{
${ }^{8}$ Tranching is the process of transforming the risk-return profiles and credit risk exposures of an asset pool into different risk classes with differing seniority in bankruptcy and timing of default.

${ }^{9}$ This problem could be avoided if the transferred assets could be broken up into different pools, each of which is assigned to a different SPE, with each pool of assets being used to back the issuance of a single homogeneous type of debt instrument. Legal squabbles over priority in the event of default would be avoided. However, splitting up the assets into legally distinct pools could be prohibitively costly or impossible. For example, it is not obvious how the S-O could split the cash flows of a portfolio of bonds into interest and principal and place each in different firewalled entities.

${ }^{10}$ In addition, if the S-O agrees to buy back non-performing assets, the S-O will not qualify for sale accounting.

${ }^{11}$ A primary reason why third party credit enhancement is uncommon is that information asymmetry prevents the third party from being willing to offer such guarantees except at a prohibitively high cost. Of course, such a cost would reduce the incentive to use asset securitization as a means to issue debt.
} 
the S-O absorbs much of the SPE's risk. The larger the retained interest, the larger the risk borne by the S-O, the more remote the prospect of the SPE defaulting, but the greater the risk that a court might query whether a true sale had taken place (Stark, 2002, p. 218). The S-O therefore has to make a tradeoff between the costs associated with the bankruptcies of the two entities.

The key empirical matter this paper investigates is whether the accounting for securitization transactions covered by SFAS 140 properly reflects the underlying economics of the transactions. From an accounting perspective, such transactions involve removal of the securitized assets from the S-O's balance sheet and, if additional considerations described above are met, non-consolidation of the SPE's debt with that of the S-O. From an economic perspective, an economic true sale occurs if the risks and rewards associated with the transferred assets and the debt issued by the SPE reside fully with the SPE or a third party. Because retained interest acts as a guarantee for the SPE's creditors, the risk transfer is incomplete. As noted above, the larger the retained interest, the larger the risk borne by the S-O. Below, we address the question whether the market views the typical securitization transaction as a sale (risk transfer) or as a secured borrowing (little or no risk transfer) by estimating cross-sectional valuation regressions. In addition, we also examine whether the amount of retained interest affects the market's perception of the amount of risk transfer.

It is important to recognize that our analysis does not assume that securitization transactions are motivated by a desire to manage earnings. ${ }^{12}$ Rather, the objective is to place a fire wall around the assets that are to be used as collateral for the securities issued by the SPE. It is essential that the courts would recognize any transfer of assets from the S-O to the SPE as a

\footnotetext{
${ }^{12}$ See Dechow, Myers, and Shakespeare (2004) and Shakespeare (2004) for further discussion and empirical evidence. Banks and other financial institutions subject to regulatory capital requirements are particularly likely to be affected by the desire to engage in securitizations to manage not just earnings but also regulatory capital. See section 6.4 below.
} 
genuine sale to maintain ex post the ex ante priorities between the different debt securities of the two entities. From this perspective, the accounting treatment matters if and only if the choice of treatment influences the judgment of the court about the status of the sale in the event of a subsequent dispute. ${ }^{13}$ The existence of recourse arrangements can play a part here as well. It is an open issue whether continuing involvement of the S-O in the financial affairs of the SPE in the form of a retained interest would affect the court's judgment about the status of the sale. We assume market participants take account of such uncertainties when valuing the S-O's stock. In particular, when assessing how retained interest affects the value of the S-O's stock, market participants have to judge not only whether and to what degree the S-O will absorb the financial risk stemming from the SPE's assets, but also the court's position on whether a true sale has occurred and therefore whether the S-O's creditors have claim to the SPE's assets in the event of the S-O's bankruptcy. Although we take into account the amount of retained interest in some of our regressions, we have no way to disentangle the degree to which each of the two judgments separately is reflected in the valuation of the S-O's stock. Nonetheless, we expect the greater is the retained interest, the less risk transfer is likely to have taken place.

\section{Empirical Design}

\subsection{Estimating Equations for the Typical Sponsor-Originator}

The study's primary research question is whether the market views asset securitization transactions as sales or a form of implicit borrowing by the S-O. The question can be rephrased as whether economically the risks and rewards associated with the transferred assets and the debt issued by the SPE reside with the S-O or the SPE. We address this question by estimating a

\footnotetext{
13 "Although not dispositive, courts have examined the transaction agreements for evidence of intent. How the originator accounted for the transfer on its books and records may be probative" (Stark, 2002, p. 219).
} 
cross-sectional valuation model similar to that used by Landsman (1986). That study addresses a different but economically similar research question, i.e., whether the market views defined benefit pension plan assets and obligations as assets of the sponsoring firm or whether the risks and rewards of pension activity are transferred to the firm's employees and retirees. Following the vast empirical literature based on the insights of Ohlson (1995), our estimating equations differ from Landsman (1986) in that they include a measure of earnings. All regressions are estimated using per share amounts.

We begin by estimating a benchmark regression, given by equation (1), for the S-O firms, without consideration of SPE assets and liabilities, i.e., before consolidation.

$$
M V E_{i t}=a_{0}+a_{1} A S S E T_{i t}+a_{2} L I A B_{i t}+a_{3} N I_{i t}+e_{i t},
$$

where $M V E$ is equity market value, ASSET and $L I A B$ are book value of total assets and liabilities, and $N I$ is net income, all measured on a per share basis. ASSET and $L I A B$ are measured at fiscal year end, $M V E$ is measured three months after the fiscal year end, and the $i$ and $t$ subscripts denote firm and year respectively. Based on prior research, we predict $a_{1}=1, a_{2}=-1$, and $a_{3}>0$

The next model we estimate, equation (2), consolidates the S-O and SPE balance sheets. ${ }^{14}$

$$
M V E_{i t}=a_{0}+a_{1} N E W_{-} A_{S S E T S}+a_{2} N E W_{-} L I A B_{i t}+a_{3} A D J_{-} N I_{i t}+e_{i t}
$$

$N E W_{-} A S S E T$ and NEW_LIAB are total assets and liabilities on a consolidated basis. ${ }^{15}$ In particular, NEW_ASSETS equals the S-O assets, ASSET, minus the sum of retained interests, RET_INT, and servicing rights, MSR, plus the SPE's assets, SPE_ASSET. We define $S P E \_$ASSET as managed loans disclosed in the financial statements. We consider two alternative

\footnotetext{
${ }^{14}$ See section 5.2 for a description of the consolidation procedure.

${ }^{15}$ For ease of exposition, we use the same notation for coefficients and error terms for each of the estimating equations. In all likelihood they differ across equations.
} 
measures for $N E W_{-} L I A B$ : NEW_LIAB_HIGH and NEW_LIAB_LOW. NEW_LIAB_HIGH equals S-O liabilities, LIAB, plus SPE_ASSET. Thus, NEW_LIAB_HIGH represents an extreme case which presumes that the SPE is capitalized solely with debt. $N E W_{-} L I A B_{-} L O W$ equals $N E W_{-} L I A B_{-} H I G H$ minus the sum of RET_INT and MSR. As described in section 5.2, $N E W_{-} L I A B \_L O W$ represents a partial adjustment to reflect the capital retained by the S-O. Finally, $A D J \_N I$ is the S-O's net income less gains (losses) from current year securitization activities, and it is therefore an income measure reflecting consolidation.

Equation (2) addresses the question whether the market views the typical asset securitization as a partial or complete risk transfer. In particular, it makes no distinction between those S-O firms that utilize a relatively high proportion of retained interest and those that use a relative low proportion. As with equation (1), if the market views the SPE's assets and liabilities as belonging to the S-O, we predict $a_{1}=1, a_{2}=-1$, and $a_{3}>0$. However, if the market views the securitization transactions as being partial or complete risk transfers—with a complete transfer being economically equivalent to sales - then we predict $a_{1}<1$ and $a_{2}>-1$ as the coefficients will reflect the average valuation effects of the S-O's recognized assets and liabilities and the SPE's assets and liabilities that do not fully belong to the S-O.

To test the main hypothesis whether the market views the typical asset securitization economically as a sale or secured borrowing, we decompose $N E W_{-} A S S E T$ and $N E W_{-} L I A B$ into their primary components, permitting the components to have different coefficients. Equation (3) uses S-O accounting amounts adjusted for the effects of consolidation.

$$
\begin{aligned}
M V E_{i t}= & a_{0}+a_{1} A D J_{-} A S S E T_{i t}+a_{2} L I A B_{i t}+a_{3} S P E_{-} A S S E T_{i t}+ \\
& a_{4} S P E_{-} L I A B_{i t}+a_{5} A D J_{-} N I_{i t}+e_{i t}
\end{aligned}
$$


$A D J \_A S S E T$ and $L I A B$ are, respectively, NEW_ASSET less SPE_ASSET and NEW_LIAB less

SPE_LIAB. Our predictions are as follows. If the market views the typical asset securitization as a sale, then $a_{3}=a_{4}=0$. On the other hand, if the market views securitized assets and liabilities as assets and liabilities of the typical S-O, then $a_{3}=a_{1}$ and $a_{4}=a_{2}$. An intermediate case is also possible, whereby the market views the typical securitization as representing a partial risk transfer, for which we predict $a_{1}-a_{3}>0$ and $a_{4}-a_{2}>0$.

\subsection{Random assignments of SPE assets and liabilities}

A common concern with cross-sectional valuation models stated in levels is correlated omitted variable bias, in particular scale bias (Barth and Kallapur, 1996; Easton and Sommers, 2003). Of particular concern in our study is that SPE assets and liabilities could appear to be priced as S-O assets and liabilities because of the effects of scale. To address this concern, we conduct the following randomization test. In particular, we randomly assign SPE assets and liabilities associated with a particular S-O as belonging to another S-O, scaling up (or down) the magnitude of the randomly assigned SPE assets and liabilities based on relative size - equity market value of the "recipient" S-O and the "donor" S-O. We then estimate equation (3) using the randomly assigned SPE assets and liabilities, and repeat this procedure 1,000 times. If scale is the cause of $a_{3}$ and $a_{4}$ differing from zero when estimating equation (3) using actual data, then the mean coefficients from this bootstrapping procedure should look similar to those based on actual data and the bootstrapped $a_{3}$ and $a_{4}$ coefficients should consistently differ from zero. On the other hand, if scale has little effect on $a_{3}$ and $a_{4}$ estimated using actual data and there is no underlying relation between SPE assets and liabilities and S-O equity market value, then the mean $a_{3}$ and $a_{4}$ coefficients from the bootstrapping procedure will be zero. 


\subsection{Estimating Equations partitioning on Retained Interest}

As explained in section 3, retained interest is a common feature of securitization transactions. Retained interest effectively represents an equity stake in the SPE by the S-O, and thereby acts as a guarantee for the SPE's creditors. The risk transfer is incomplete: the larger is the amount of retained interest, the larger the risk borne by the S-O. To assess whether the valuation effects of SPE assets and liabilities differ depending on the amount of retained interest, we estimate equation (3) separately for "high" and "low" retained interest S-Os. We classify firms as being high (low) retained interest S-O firms with retained interest above (below) the median amount of retained interest as a proportion of S-O total assets, i.e., RET_INT/ASSETS. We predict that high retained interest S-O firms will be valued as if there is less risk transfer than for the low retained interest firms. That is we predict $a_{3}\left(a_{4}\right)$ for high retained interest S-O firms is larger (smaller, i.e., more negative) than $a_{3}\left(a_{4}\right)$ for low retained interest S-O firms. In the extreme, the market will value high (low) retained interest firms as if no (full) risk transfer occurs, i.e., $a_{3}=a_{1}$ and $a_{4}=a_{2}\left(a_{3}=a_{4}=0\right)$.

In principle, a classification scheme more consistent with the theory of risk transfer is one based on retained interest as a proportion of SPE assets. That is, from the perspective of the SPE's capital providers (who are principally lenders), the primary issue for them-assuming the existence of a fire wall between the SPE and the S-O that will prevent the S-O's creditors from making claims on the SPE's assets-is the extent to which the S-O will cover any shortfalls in the securitized assets' contractual cash flows. A relevant proxy for the S-O's commitment to cover such shortfalls is the relative size of retained interest to SPE assets. Unfortunately, the only measure of SPE assets available to us (and the market) is S-O managed assets, which likely 
measure SPE assets with error. ${ }^{16}$ What is readily available to the market is the ratio of retained interest to S-O assets. In addition, there reasons to expect this to be a good proxy measure that the market uses. First, it is likely correlated with the unobservable ratio of retained interest to SPE assets (larger S-O firms tend to have more asset securitizations). Second, the greater is the proportion of retained interest to S-O assets, the more important it is to the valuation of the S-O's stock.

\subsection{Estimation separating regulated and non-regulated firms}

As noted in section 3, relative to unregulated entities, regulated S-Os have additional incentives to engage in securitization transactions that are represented for accounting purposes as sales. We therefore examine regulated and unregulated firms separately when addressing how the market views asset securitizations by estimating equation (3) separately for regulated and unregulated firms. We define a firm as being regulated if it discloses in its footnotes that it has paid FDIC insurance. This includes regulated financial institutions within the following three SIC categories: 6021, 6022, and 6036.

\section{Sample and Data}

\subsection{Sample}

We used the Securities and Exchange Commission’s (SEC) Electronic Data Gathering, Analysis, and Retrieval (EDGAR) system to search the 10-K forms of all firms filing with the SEC during the period December 2000 to January 2004 inclusive. The choice of time period reflects the date after which SFAS 140 became effective, and hence the date after which the

\footnotetext{
${ }^{16}$ Measurement error associated with using managed assets as proxy for SPE assets is likely to be a more serious problem when attempting to classify firms based on the ratio of retained interest to managed assets than when the level of managed assets is used as proxy for SPE assets in our valuation equations. The reason is that whereas measurement error can lead to misclassification of high and low retained interest firms, it will only lead to a bias towards zero for the SPE asset and liability coefficients in the valuation equations.
} 
securitization disclosure information needed to conduct the study became available. We identify all firms who (a) are identified as S-Os by reason of having SFAS 140 disclosures, and (b) their SFAS 140 disclosures include the total principal amount of financial assets that the S-O manages as of fiscal year end that have previously been securitized. This yields a sample of 297 firm year observations representing 112 firms. When a sample firm does not disclose amounts for retained interest, servicing rights and gains on sale, we assume that these amounts are immaterial and set these variables to zero.

Because we estimate all regressions on a per share basis, all variables described below are deflated by common shares outstanding three months after year end (Compustat data item 61). Following common practice to ensure stock prices reflect information in financial statements, we define the dependent variable, $M V E$, as price three months after the year end (data item 14) multiplied by common shares outstanding three months after year end (data item 61). We measure S-O total assets and liabilities, ASSET, and LIAB, as data items 6 and 181, and net income, $N I$, as data item 172. The remaining variables, ADJ_ASSET, NEW_ASSET, SPE_ASSET, NEW_LIAB_HIGH, NEW_LIAB_LOW, and $A D J \_N I$, are as defined in the consolidation procedure section (section 5.2) and referenced in section 4.1.

Tables 1 and 2 present sample summary statistics and correlations for the variables used in equations (1), (2), and (3), together with the two variables used to construct some of the independent variables, retained interest (RET_INT) and servicing rights (MSR). Table 1 indicates that consolidation of the S-O and SPE balance sheets has a substantial economic effect. For example, mean (median) SPE assets and liabilities, SPE_ASSET and SPE_LIAB, are 46.44 and 40.05 (9.67 and 8.32); mean (median). Mean (median) S-O assets and liabilities, ASSET and $L I A B$, are 118.33 and 104.65 (98.25 and 80.15). Therefore, consolidation increases mean 
(median) total assets and liabilities, NEW_ASSET and NEWLIAB_LOW, of the combined entity to 158.38 and 144.70 (124.78 and 114.76). Thus, in terms of means, consolidation increases total assets and liabilities by approximately $33 \%$. Table 1 also indicates that mean (median) retained interest, RET_INT, is $12.7 \%$ (9.5\%) of mean (median) SPE assets, SPE_ASSET. In addition, the ratio of RET_INT to SPE_ASSET exhibits wide cross-sectional variation.

Table 2 indicates that each of the asset and liability measures is highly correlated with each other and with stock price. Interestingly, the bivariate correlation between stock price, $M V E$, and SPE_ASSET is negative, although this does not imply that the partial correlation between the two measures is negative.

\subsection{Consolidation Procedure ${ }^{17}$}

We employ the following procedure to consolidate the activities of the SPE back into the financial statements of the sponsor firm. First, we set the SPE assets equal to the off balance sheet portion of the managed portfolio of financial assets that are disclosed in the S-O's financial statements. ${ }^{18}$ The SPE liability to third parties is more difficult to estimate as SFAS 140 requires no specific disclosures of the SPE's outstanding liabilities. However, it is possible to determine a possible range for the true liability. At the highest end of the range, we set the SPE liability equal to the SPE asset. The cash collections from these assets are used to repay the liability. Therefore, we assume that the liability can never be higher than the assets yet to be collected. This estimate of the SPE's liability is likely overstated as securitizations are generally structured with retained interests. As a result, the estimate would be overstated by the carrying amount of the retained interest. Unfortunately, SFAS No. 140 only requires firms to disclose the fair value

\footnotetext{
${ }^{17}$ We greatly appreciate discussions with Barbara Havlicek of Moodys about the best consolidation method.

${ }^{18}$ Ideally, we would obtain SPE asset and liability information directly from their financial statements. Unfortunately, these are not readily available. Therefore, our procedure reflects an attempt to estimate SPE assets and liabilities from the S-O SFAS 140 disclosures. It should also be noted that SFAS 140 disclosures do not include assets that had previously been securitized but the S-O no longer manages (see SFAS 140, footnote 10).
} 
of the retained interest. Therefore, a conservative estimate of the true liability to third parties is the SPE's assets minus the sum of the fair value of the retained interest and the carrying value of any other related amounts on the sponsor's balance sheet, i.e., servicing rights.

Second, we adjust the S-O's assets by removing fair value of the retained interests and any recognized servicing assets or liabilities from the balance sheet to state the S-O's assets on an "as if" no sale had occurred basis. We add our estimate of the SPE's assets to this restated SO asset amount to obtain an estimate of the S-O's total assets assuming that the SPE is consolidated with the S-O. Similarly, we add our estimate of the SPE liability to the S-O's liabilities to obtain an estimate of the consolidated liability. Note, when we estimate equations (3) and (4), which include separately restated S-O assets and liabilities and SPE assets and liabilities, we cannot estimate the equations using the high liability estimate. This is because the SPE high liability, by construction, exactly equals SPE assets and therefore induces perfect collinearity in the regression. We adjust current net income by subtracting current gains from securitizations transactions. ${ }^{19}$

\section{Empirical Results}

\subsection{Specifications for Full Sample}

Table 3 presents regression summary statistics associated with estimation of equation (1), the benchmark model before consolidation of the S-O and SPE balance sheets. ${ }^{20}$ Consistent with prior research and predictions, we cannot reject the null that $a_{1}=1, a_{2}=-1$, and $a_{3}>0$. In

\footnotetext{
${ }^{19}$ Note that our consolidation procedure is incomplete in that it is not possible from the SFAS 140 disclosures to discern the amount of interest receivable and payable from the securitized assets and liabilities. However, servicing income paid by the SPE to the S-O likely approximates the difference between the two interest amounts.

${ }^{20}$ Untabulated findings from estimating equations (1) through (3) in ranks and using year fixed-effects indicate no changes in inferences from those relating to the tabulated findings.
} 
particular, the respective untabulated t-statistics for the tests of $a_{1}=1$ and $a_{2}=-1$ are 0.49 and -0.85 .

Table 4 presents regression summary statistics associated with estimation of equation (2), which includes total assets and liabilities on a post-consolidation basis. Panel A (B) includes findings based on using NEW_LIAB_HIGH (NEW_LIAB_LOW) as the estimate of SPE total liabilities. Although findings in both panels indicate that the total consolidated asset and liability coefficients have predicted signs, only the panel B findings are fully consistent with the prediction that the SPE's assets and liabilities belong to the S-O. In particular, whereas the untabulated t-statistics associated with panel A for the tests of $a_{1}=1$ and $a_{2}=-1$ are 8.26 and -9.44, the corresponding panel B t-statistics are 1.07 and -0.57 . In addition, whereas the model explanatory power in panel A, $46 \%$, is substantially below that of the base model in table 3 , $59 \%$, the model explanatory power in panel B, $56 \%$ is similar to that of the base model. Together, these two findings suggest that the more conservative liability measure for SPE liabilities is the more sensible one, which is fortuitous because that is the one we are limited to using in tests in which the S-O and SPE total assets and liabilities are included as separate regressors.

Table 5 presents regression summary statistics associated with estimation of equation (3), which permits the coefficients on S-O total assets and liabilities and SPE total assets and liabilities to differ. Findings indicate that the market views SPE assets and liabilities similarly to $\mathrm{S}-\mathrm{O}$ assets and liabilities. In particular, untabulated t-statistics associated with the test of the asset coefficients being equal to 1 and the liability coefficients being equal to -1 are each insignificant (the respective t-statistics for $a_{1}=1, a_{2}=-1, a_{3}=1, a_{4}=-1$ are $0.1,-0.66,0.55$, 
and -0.62). This finding indicates that SPE asset and liabilities are valued as belonging to the SO when S-O assets, liabilities, and net income are restated to reflect the effects of consolidation.

These findings also are supported by the F-statistics associated with the test whether the market values S-O and SPE assets and liabilities similarly, i.e., as if $a_{3}=a_{1}$ and $a_{4}=a_{2}$. The Fstatistics, 1.00 and 3.02, are respectively insignificant and marginally significant (critical F at 5\% level is 2.15). ${ }^{21}$ Taken together, the findings in table 5 suggest that when the S-O and SPE are consolidated, the evidence suggests that the market views the typical asset securitization as a loan, not as a sale.

It is also interesting to note that the $\mathrm{S}-\mathrm{O}$ asset and liability coefficients in table 5 are nearly identical to those in table 3. Thus, adding SPE assets and liabilities to the equity valuation equation that already includes S-O assets and liabilities has little impact on the S-O asset and liability coefficients. This finding suggests that although the market views SPE assets and liabilities as belonging to the S-O, it also views the activities of the SPE as being separable from those of the S-O. This is not surprising given that only separable assets can be used as a basis for securitization.

\subsection{Randomization tests}

Table 6 presents the findings from the bootstrapping procedure in which equation (3) is reestimated after scaled SPE assets and liabilities are randomly assigned from one S-O to another. We report the mean coefficients from the 1,000 estimations and the number of times $a_{3}$ and $a_{4}$, the SPE asset and liability coefficients, differ from zero.

\footnotetext{
${ }^{21}$ The reason for rejecting $a_{4}=a_{2}$ is that the SPE liability coefficient, -1.07 , is even more negative than the S-O liability coefficient, -0.99 . This result is consistent with SPE liability understating the true liability.
} 
The findings in table 6 indicate that randomly assigned SPE assets and liabilities are not valued as belonging to the recipient S-O. Even though the Fama-MacBeth t-statistics are significant, the economic magnitudes of the mean coefficients are essentially zero, 0.0001 and -0.0001 , respectively, for SPE assets and liabilities. In addition, the number of significant randomly assigned SPE asset and liability coefficients is approximately $14 \%$. The key conclusion to be drawn from table 6 is that randomly assigning SPE assets and liabilities from one S-O to another, adjusting for scale differences between the S-Os, indicates that scale is not a factor that can explain the findings in table 5. This is additional evidence to support the conclusion that the market views SPE assets and liabilities as belonging to the S-O.

\subsection{Specifications for Retained Interest Partitionings}

Table 7, panels A and B, presents findings associated with estimation of equation (3) for low and high retained interest subsamples. If the market considers the degree of risk transfer to be different for high and low retained interest S-O firms, then SPE asset and liability coefficients for high retained interest S-O firms will be larger in absolute magnitude than will be those for low retained interest S-O firms. In the extreme, if risk transfer is complete for low retained interest S-O firms, then their SPE asset and liability coefficients will be zero; if there is no risk transfer for high retained interest S-O firms, then their S-O and SPE asset and liability coefficients will be similar.

The findings in table 7 indicate that the market views high and low retained interest S-O firms differently. In particular, whereas the market views asset securitizations by low retained interest S-O firms as sales, i.e., risk transfer has taken place, it views asset securitizations by high retained interest $\mathrm{S}-\mathrm{O}$ firms as secured borrowings, i.e., risk transfer is incomplete. For the low retained interest $\mathrm{S}-\mathrm{O}$ firms, the $S P E_{-} A S S E T$ and $S P E_{-} L I A B$ coefficients are insignificantly 
different from zero $\left(S P E \_A S S E T\right.$ coefficient $=-0.12(\mathrm{t}-\mathrm{statistic}=-0.16), S P E_{-} L I A B$ coefficient

$=0.27(\mathrm{t}$-statistic $=0.33))$. In contrast, the respective coefficients for the high retained interest SO firms are significantly positive and negative and similar in magnitude to the coefficients for the assets and liabilities of the S-O, ADJ_ASSET and LIAB (SPE_ASSET coefficient $=0.87$ (tstatistic $=6.08), S P E_{-} L I A B$ coefficient $=-0.88(\mathrm{t}$-statistic $\left.=-6.08)\right) .{ }^{22}$

Untabulated findings indicate that retained interest varies systematically across S-O

firms. In particular, retained interest is lowest for multiple securitizers, and it varies by type of securitized asset, being lowest for mortgages and business receivables and highest for credit card receivables. These results are consistent with SPE bondholders seeking least assurance from S-O firms that repeatedly securitize their assets (the reputation effect) and for assets were the market is long-standing and highly active.

\subsection{Regulated and Unregulated firm estimations}

The final set of analyses relate to partitioning the sample into regulated and unregulated firms. Banks and other financial institutions subject to regulatory capital requirements have additional incentives to engage in asset securitizations for the purpose of managing income and regulatory capital. ${ }^{23}$ Under present international regulatory capital requirements, the equity tranche retained by the originating bank cannot be used to support any additional bank liabilities. That is, any retained interest held on the balance sheet attracts a dollar-for-dollar capital requirement. This has purportedly led some banks to engage in off-balance sheet transactions to

\footnotetext{
${ }^{22} \mathrm{We}$ also used managed assets to partition the sample of S-O firms into high and low retained interest subsamples. Consistent with the concern we raise in section 4.3 regarding the potential effects of measurement error associated with using managed assets to measure the proportion of retained interest, findings from untabulated regressions indicate a general weakening of inferences.

${ }^{23}$ Although banking regulators generally acknowledge that securitization can be an important method for redistributing risks and diversifying portfolios, they are concerned that securitizations not be used as a means of circumventing capital requirement constraints (Committee on the Global Financial System, 2003). To the extent that a dollar of assets removed by securitization transactions also removes a dollar of bank liabilities, the need for regulatory capital is reduced.
} 
sell the equity tranche to a third party by means of a total returns swap (Wolfe, 2004). ${ }^{24}$ Relative to unregulated entities, regulated S-Os have additional incentives to engage in securitization transactions that are represented for accounting purposes as sales. Therefore, as a final analysis, we reestimate equation (3) separately for regulated and unregulated firms to assess whether the market views asset securitizations differently for the two groups.

Table 8, panels A and B, presents findings for regulated and unregulated firms. The findings in both panels indicate that the market views securitization transactions as secured borrowings rather than sales. In particular, in both panels, the SPE asset and liability coefficients have predicted signs and have magnitudes that are significantly greater than zero. The primary difference between the two sets of firms is that whereas all of the regulated firm asset and liability coefficients are well in excess of 1 and -1 , the unregulated firm asset and liability coefficients are below 1 and -1 , but closer to these predicted values. Another notable difference is that the model explanatory power for regulated firms, $82 \%$, is $70 \%$ larger than that for unregulated firm, $48 \%$. Taken together, these findings indicate that asset securitizations are valued by the market as if they are secured borrowings rather than sales, regardless of whether the S-Os are regulated or unregulated. If anything, the evidence is stronger for regulated firms than for unregulated firms. This is consistent with the notion that regulated firms have additional incentives to use a legal structure to remove debt from their balance sheets when economically they retain full property rights to the assets transferred to the SPE and obligations taken on by the SPE.

\section{Summary and Concluding Remarks}

\footnotetext{
${ }^{24}$ Consistent with the prediction that regulated firms have the incentive to eliminate retained interest from the balance sheet, for our sample, untabulated findings indicate that, relative to regulated S-Os, unregulated S-Os have approximately ten times the amount of retained interest as a fraction of total assets.
} 
The primary question this study addresses is whether asset securitizations are really asset sales or a form of secured borrowing. We address this question by estimating cross-sectional equity valuation regressions to assess whether the stock market treats securitized assets and liabilities held by an SPE as assets and liabilities of the S-O. We find that the market views the SPE assets and liabilities as belonging to the S-O, i.e., the risk and rewards of ownership of the transferred assets reside with the S-O and not the SPE. Results from a boot-strapping simulation that controls for scale by randomly assigning SPE assets and liabilities from one S-O to another provide evidence that scale bias is an unlikely explanation for finding the market views SPE assets and liabilities as belonging to the S-O.

The second research question we address is whether the amount of retained interest arising from its securitization transactions affects the market's perception of the degree to which risk has been transferred to the SPE. We find that whereas the market views asset securitizations by low retained interest $\mathrm{S}-\mathrm{O}$ firms as sales, i.e., risk transfer has taken place, it views asset securitizations by high retained interest $\mathrm{S}-\mathrm{O}$ firms as secured borrowings, i.e., risk transfer is incomplete.

We also find that although the market views securitizations by regulated and unregulated $\mathrm{S}-\mathrm{Os}$ as secured borrowing, there is suggestive evidence that regulated firms have greater incentives to use securitizations to achieve off-balance sheet financing. 


\section{References}

Bond Market Association, 2004. http://www.bondmarkets.com/Research/statist.shtml, January 7. Committee on the Global Financial System, 2003. Credit Risk Transfer. Bank of International Settlements.

Dechow, P.M., L.A. Myers, and C. Shakespeare, 2004. Playing with Assumptions to Report a Rosy Future Today: The Role of Corporate Governance in the Reporting of Asset Securitizations. Working paper, University of Michigan

Easton, P.D., and G.A. Sommers, 2003. Scale and Scale Effects in Market-Based Accounting Research. Journal of Business Finance and Accounting. January/March, Vol. 30: 25-55.

Financial Accounting Standards Board, 2000. Statement of Financial Accounting Standards No. 140, Accounting for Transfers and Servicing of Financial Assets and Extinguishments of Liabilities. FASB: Norwalk, Conn

Financial Accounting Standards Board, 2003. Financial Interpretation No. 46, Consolidation of Variable Interest Entities. FASB: Norwalk, Connecticut.

Hansmann, H., R. Kraakman, and R. Squire, 2006. Law and the rise of the firm. Working paper, Yale Law School.

Gorton, G., and N.S. Souleles, 2004. Special Purpose Vehicles and Securitization. Working paper, University of Pennsylvania.

Landsman, W.R., 1986. An empirical investigation of pension fund property rights. The Accounting Review. October, Vol. 61: 662-691.

Moody’s Investors Service, 2002. Special Comment: Securitization and its Effect on the Credit Strength of Companies.

Nui, F.F., and G.D. Richardson, 2004. Earnings Quality, Off-Balance Sheet Risk, and the 
Financial-components Approach to Accounting for Transfers of Financial Assets. Working paper, University of Toronto.

Ohlson, J.A., 1995. Earnings, Equity Book Values, and Dividends in Equity Valuation. Contemporary Accounting Research, 66-687.

Securities and Exchange Commission, 2005. Report and Recommendations Pursuant to Section 401(c) of the Sarbanes-Oxley Act of 2002 On Arrangements with Off-Balance Sheet Implications, Special Purpose Entities, and Transparency of Filings by Issuers.

Shakespeare, C., 2004. Do Managers Use Securitization Volume and Fair Value Estimates to Hit Earnings Targets? Working paper, University of Michigan.

Stark, R., 2002. Viewing the LTV Steel ABS Opinion in its Proper Context. Journal of Corporation Law. Winter, Vol. 27: 211-229.

Wolfe, S., 2004. Equity toxic waste in asset-backed securitisation. Working paper, University of Southampton. 
Table 1

Descriptive Statistics for 297 Sponsor Firm Observations

All amounts are per share

\begin{tabular}{l|ccccccc}
\hline Variable & Mean & Median & Std Dev & $25 \%$ & $75 \%$ & Min. & Max. \\
\hline MVE & 27.15 & 22.125 & 20.38 & 11.90 & 39.71 & 0.035 & 104.00 \\
ASSET & 118.33 & 98.25 & 103.35 & 35.26 & 176.41 & 1.92 & 526.93 \\
LIAB & 104.65 & 80.15 & 99.16 & 21.69 & 163.22 & 1.43 & 483.43 \\
ADJ_ASSET & 111.94 & 88.78 & 99.55 & 32.09 & 164.23 & 0.92 & 507.61 \\
NEW_ASSET & 158.38 & 124.78 & 165.61 & 40.69 & 215.82 & 1.87 & $1,388.82$ \\
NEW_LIAB_HIGH & 151.09 & 117.74 & 180.70 & 29.81 & 202.10 & 1.85 & $1,618.04$ \\
NEW_LIAB_LOW & 144.70 & 114.76 & 162.74 & 27.39 & 200.45 & 1.53 & $1,374.55$ \\
SPE_ASSET & 46.44 & 9.67 & 131.24 & 3.15 & 35.73 & 0.01 & $1,238.91$ \\
SPE_LIAB & 40.05 & 8.32 & 110.95 & 2.41 & 28.44 & -9.34 & 995.42 \\
NI & 1.06 & 1.29 & 3.06 & 0.21 & 2.34 & -22.65 & 12.77 \\
ADJ_NI & -0.17 & 0.92 & 7.03 & -0.15 & 2.12 & -68.15 & 8.90 \\
RET_INT & 5.08 & 0.92 & 18.81 & 0.26 & 3.49 & -1.18 & 203.01 \\
MSR & 1.31 & 0.00 & 6.76 & 0.00 & 0.17 & -13.44 & 49.69 \\
\hline
\end{tabular}

Notes:

$M V E$ is defined as price 3 months after the year end (data item 14) multiplied by common shares outstanding 3 months after year end (data item 61); ASSET is defined as data item 6 from Compustat; LIAB is defined as data item 181 from Compustat; $A D J$ ASSET is defined as Asset less RET INT and MSR; $N E W \_A S S E T$ is defined as $A D J$ ASSET plus SPE_ASSET; NEW_LIAB_HIGH is defined as Liab plus $S P E_{-} \bar{A} S S E T ; N E W_{-} L I A B_{-} L O W \bar{W}$ is defined as $L I A \bar{B}$ plus SPE_ASSET less RET_INT and MSR; SPE_Asset is defined as managed loans off balance sheet disclosed in the financial statements; SPE_LIAB is defined as SPE_ASSET less RET_INT and MSR; NI is defined as data item 172 from Compustat; $A D J$ NI is defined as $N I$ less gains (losses) from current year securitization activities; $R E T \_I N T$ is defined as retained interests from securitization transactions; MSR is defined as servicing rights from securitization activities; Price is defined as price 3 months after the year end (data item 14). All variables are measured on a per share basis, by deflating by common shares outstanding 3 months after year end (data item 61). 
Table 2

Correlations

Pearson (Spearman) correlations above (below) the diagonal. All variables are measured on a per share basis

\begin{tabular}{|c|c|c|c|c|c|c|c|c|c|c|c|c|c|}
\hline & $M V E$ & $A S S E T$ & LIAB & $N E W \_A S S E T$ & NEWLIAB_HIGH & NEWLIAB_LOW & ADJ_ASSET & SPE_ASSET & SPE_LIAB & RET_INT & $M S R$ & $N I$ & $A D J \_N I$ \\
\hline$M V E$ & 1.00 & 0.477 & 0.455 & 0.207 & 0.155 & 0.185 & 0.516 & -0.130 & -0.135 & -0.150 & 0.112 & 0.525 & 0.269 \\
\hline ASSET & 0.479 & 1.00 & 0.998 & 0.755 & 0.702 & 0.740 & 0.974 & 0.212 & 0.193 & 0.197 & 0.393 & 0.323 & -0.120 \\
\hline$L I A B$ & 0.445 & 0.991 & 1.00 & 0.755 & 0.705 & 0.744 & 0.972 & 0.215 & 0.197 & 0.198 & 0.383 & 0.305 & -0.126 \\
\hline$N E W \_A S S E T$ & 0.345 & 0.924 & 0.914 & 1.00 & 0.995 & 0.999 & 0.610 & 0.799 & 0.791 & 0.725 & 0.522 & 0.090 & -0.609 \\
\hline NEWLIAB_HIGH & 0.285 & 0.897 & 0.906 & 0.986 & 1.00 & 0.996 & 0.542 & 0.844 & 0.831 & 0.786 & 0.561 & 0.059 & -0.671 \\
\hline$N E W L I A B \_L O W$ & 0.302 & 0.907 & 0.916 & 0.988 & 0.998 & 1.00 & 0.595 & 0.810 & 0.802 & 0.733 & 0.515 & 0.073 & -0.620 \\
\hline$A D J A S S E T$ & 0.521 & 0.985 & 0.976 & 0.880 & 0.848 & 0.862 & 1.00 & 0.011 & 0.003 & -0.023 & 0.232 & 0.347 & 0.080 \\
\hline$S P E \_A S S E T$ & -0.174 & 0.282 & 0.290 & 0.527 & 0.577 & 0.553 & 0.207 & 1.00 & 0.995 & 0.932 & 0.483 & -0.149 & -0.829 \\
\hline$S P E_{-} L I A B$ & -0.166 & 0.271 & 0.280 & 0.518 & 0.564 & 0.545 & 0.200 & 0.983 & 1.00 & 0.898 & 0.413 & -0.166 & -0.797 \\
\hline$R E T \_I N T$ & -0.335 & 0.033 & 0.037 & 0.244 & 0.298 & 0.263 & -0.054 & 0.719 & 0.629 & 1.00 & 0.574 & -0.109 & -0.870 \\
\hline$M S R$ & 0.116 & 0.460 & 0.476 & 0.436 & 0.454 & 0.453 & 0.429 & 0.212 & 0.173 & 0.101 & 1.00 & 0.126 & -0.590 \\
\hline$N I$ & 0.685 & 0.467 & 0.450 & 0.409 & 0.391 & 0.392 & 0.464 & 0.024 & 0.013 & -0.075 & 0.210 & 1.00 & 0.450 \\
\hline$A D J \_N I$ & 0.646 & 0.336 & 0.319 & 0.208 & 0.181 & 0.191 & 0.382 & -0.213 & -0.206 & -0.292 & 0.046 & 0.831 & 1.00 \\
\hline
\end{tabular}

Notes:

$M V E$ is defined as price 3 months after the year end (data item 14) multiplied by common shares outstanding 3 months after year end (data item 61 ); $A S S E T$ is defined as data item 6 from Compustat; LIAB is defined as data item 181 from Compustat; ADJ_ASSET is defined as ASSET less RET_INT and MSR;

NEW ASSET is defined as ADJ ASSET plus SPE ASSET; NEW LIAB HIGH is defined as LIAB plus SPE ASSET; NEW LIAB LOW is defined as LIAB plus SPE_ASSET less RET_INT and MSR; SPE_ASSET is defined as managed loans off balance sheet disclosed in the financial statements; SPE_LIAB is defined as $S P E \_$ASSET less RET_INT and MSR; NI is defined as data item 172 from Compustat; $A D J$ NI is defined as $N I$ less gains (losses) from current year securitization activities; RET INT is defined as retained interests from securitization transactions; $M S R$ is defined as servicing rights from securitization activities. All variables are measured on a per share basis, by deflating by common shares outstanding 3 months after year end (data item 61). 


\section{Table 3}

Base Model Regression

OLS regressions of price on assets, liabilities and net income. T-statistics are reported in brackets. All variables are measured per share. Observations where Rstudent is larger than 2 in absolute value have been deleted.

Model: $M V E_{i t}=a_{0}+a_{1} A S S E T_{i t}+a_{2} L I A B_{i t}+a_{3} N I_{i t}+e_{i t}$

\begin{tabular}{|c|c|c|c|c|c|}
\hline Intercept & ASSET & $L I A B$ & $N I$ & Adjusted $R^{2}$ & $N$ \\
\hline $\begin{array}{c}5.81 \\
(4.21)\end{array}$ & $\begin{array}{c}0.95 \\
(9.34)\end{array}$ & $\begin{array}{c}-0.91 \\
(-8.63)\end{array}$ & $\begin{array}{c}2.18 \\
(8.06)\end{array}$ & 0.5914 & 282 \\
\hline
\end{tabular}

Notes:

ASSET is defined as data item 6 from Compustat; $L I A B$ is defined as data item 181 from Compustat; $N I$ is defined as data item 172 from Compustat; $M V E$ is defined as price 3 months after the year end (data item 14) multiplied by common shares outstanding 3 months after year end (data item 61). All variables are measured on a per share basis, by deflating by common shares outstanding 3 months after year end (data item 61). 


\section{Table 4}

SPE Assets and Liabilities Consolidated back into Sponsor

OLS regressions of price on assets, liabilities and net income where SPE assets and liabilities are reconsolidated. T-statistics are reported in brackets. All variables are measured per share. Observations where Rstudent is larger than 2 in absolute value have been deleted.

Model: $M V E_{i t}=a_{0}+a_{1} N E W_{-} A_{S S E T S}+a_{2} N E W_{-} L I A B_{i t}+a_{3} A D J_{-} N I_{i t}+e_{i t}$

Panel A

\begin{tabular}{cccccc}
\hline Intercept & NEW_ASSETS & NEW_LIAB_HIGH & ADJ_NI & $\begin{array}{c}\text { Adjusted } \\
R^{2}\end{array}$ & $N$ \\
\hline & & & & & \\
10.21 & 0.41 & -0.33 & 1.12 & 0.4613 & 283 \\
$(7.26)$ & $(5.74)$ & $(-4.65)$ & $(4.71)$ & & \\
\hline
\end{tabular}

Panel B

\begin{tabular}{cccccc}
\hline Intercept & $N E W \_$ASSETS & NEW_LIAB_LOW & ADJ_NI & ${\text {Adjusted } R^{2}}^{2}$ & $N$ \\
\hline 4.13 & 1.11 & -1.06 & 1.29 & 0.5569 & 282 \\
$(2.88)$ & $(10.78)$ & $(-10.05)$ & $(9.49)$ & & \\
& & & & & \\
\hline
\end{tabular}

Notes:

ASSET is defined as data item 6 from Compustat; $L I A B$ is defined as data item 181 from Compustat; $A D J$ ASSET is defined as ASSET less RET_INT and MSR; NEW_ASSET is defined as ADJ_ASSET plus SPE_ASSET; NEW_LIAB_HIGH is defined as LIAB plus SPE_ASSET; NEW_LIAB_LOW is defined as $L I A \bar{B}$ plus SPE_ASSET less RET_INT and MSR; SPE_ASSET is defined as manage $\overline{-}$ loans off balance sheet disclosed in the financial statements; SPE_LIAB is defined as SPE_ASSET less RET_INT and MSR; NI is defined as data item 172 from Compustat; $A D J_{-} N I$ is defined as $N I$ less gains (losses) from current year securitization activities; RET_INT is defined as retained interests from securitization transactions; MSR is defined as servicing rights from securitization activities; $M V E$ is defined as price 3 months after the year end (data item 14) multiplied by common shares outstanding 3 months after year end (data item 61). All variables are measured on a per share basis, by deflating by common shares outstanding 3 months after year end (data item 61). 


\section{Table 5}

Sponsor's Assets and Liabilities and SPE's Assets and Liabilities

OLS regressions of price on sponsors assets, liabilities, net income and SPE assets and liabilities. T-statistics are reported in brackets. All variables are measured per share. Observations where Rstudent is larger than 2 in absolute value have been deleted.

\begin{tabular}{|c|c|c|c|c|c|c|c|}
\hline Intercept & $A D J \_A S S E T$ & $L I A B$ & SPE_ASSET & $S P E \_L I A B$ & $A D J \_N I$ & $\begin{array}{c}\text { Adjusted } \\
R^{2}\end{array}$ & $N$ \\
\hline $\begin{array}{c}5.30 \\
(3.74)\end{array}$ & $\begin{array}{c}0.99 \\
(9.62)\end{array}$ & $\begin{array}{c}-0.93 \\
(-8.75)\end{array}$ & $\begin{array}{c}1.06 \\
(9.67)\end{array}$ & $\begin{array}{c}-1.07 \\
(-9.41)\end{array}$ & $\begin{array}{c}0.91 \\
(4.13)\end{array}$ & 0.5595 & 283 \\
\hline$A D$ & $\begin{array}{r}A S S E T=S P I \\
L I A B=S\end{array}$ & $\begin{array}{l}A S S E T \\
E \text { LIAB }\end{array}$ & $\begin{array}{l}1.00 \\
3.02\end{array}$ & & & & \\
\hline
\end{tabular}

Notes:

ASSET is defined as data item 6 from Compustat; $L I A B$ is defined as data item 181 from Compustat; ADJ_ASSET is defined as ASSET less RET_INT and MSR; SPE_ASSET is defined as managed loans off balance sheet disclosed in the financial statements; SPE_LIAB is defined as SPE_ASSET less RET INT and $M S R$; $N I$ is defined as data item 172 from Compustat; $A \bar{D} J \_N I$ is defined as $N I$ less gains (losses) from current year securitization activities; RET_INT is defined as retained interests from securitization transactions; $M S R$ is defined as servicing rights from securitization activities; $M V E$ is defined as price 3 months after the year end (data item 14) multiplied by common shares outstanding 3 months after year end (data item 61). All variables are measured on a per share basis, by deflating by common shares outstanding 3 months after year end (data item 61). 


\section{Table 6}

Randomization tests based on 1,000 independent regressions Summary statistics of OLS regressions of price on assets, liabilities, net income and random assignment of SPE assets and SPE liabilities. All random assignments of SPE assets and liabilities are scaled by relative magnitudes of "donor" and "recipient" S-O equity market values. Fama McBeth t-statistics are reported in brackets. No. Significant obs. refers to the number of times the variable was significant (at a p-value of 0.05 or higher) for each individual regression.

\section{Model:}

\begin{tabular}{|c|c|c|c|c|c|}
\hline & $A D J A S S E T$ & $L I A B$ & SPE ASSET & $S P E \_L I A B$ & $A D J N I$ \\
\hline & $\begin{array}{c}0.75 \\
(515.41)\end{array}$ & $\begin{array}{c}-0.71 \\
(-463.96)\end{array}$ & $\begin{array}{c}0.0001 \\
(6.79)\end{array}$ & $\begin{array}{c}-0.0001 \\
(-5.72)\end{array}$ & $\begin{array}{c}2.29 \\
(362.48)\end{array}$ \\
\hline $\begin{array}{l}\text { No. } \\
\text { Significant } \\
\text { obs. }\end{array}$ & & & 142 & 146 & \\
\hline
\end{tabular}

Notes:

$M V E$ is defined as price 3 months after the year end (data item 14) multiplied by common shares outstanding 3 months after year end (data item 61); ASSET is defined as data item 6 from Compustat; LIAB is defined as data item 181 from Compustat; $A D J \_A S S E T$ is defined as ASSET less RET_INT and MSR; $S P E_{-} A S S E T$ is defined as managed loans off balance sheet randomly assigned; $S P E_{-} L I A B$ is defined as $S P E_{-} A S S E T$ less RET_INT and MSR randomly assigned; NI is defined as data item 172 from Compustat; $A D \bar{J}_{-} N I$ is defined as $\bar{N} I$ less randomly assigned gains (losses) from current year securitization activities; $R E T_{-} I N T$ is defined as retained interests from securitization transactions; MSR is defined as servicing rights from securitization activities. All variables are measured on a per share basis, by deflating by common shares outstanding 3 months after year end (data item 61). 


\section{Table 7}

Sponsor's Assets and Liabilities and SPE's Assets and Liabilities Ranked on Retained Interest

OLS regressions of price on sponsors assets, liabilities, net income and SPE assets and liabilities. T-statistics are in brackets. All variables are measured per share. Panel A (Panel B) contains observations with ranked below (above) the median of Retained Interest/Asset. Observations where Rstudent is larger than 2 in absolute value have been deleted prior to ranking the data.

Model:

$M V E_{i t}=a_{0}+a_{1} A D J_{-} A S S E T_{i t}+a_{2} A D J_{-} L_{I A B_{i t}}+a_{3} S P E_{-} A S S E T_{i t}+a_{4} S P E_{-} L_{I I A B_{i t}}+a_{5} A D J_{-} I_{i t}+e_{i t}$

Panel A Low Retained Interest / Asset

\begin{tabular}{cccccccc}
\hline Intercept & ADJ_ASSET & LIAB & SPE_ASSET & SPE_LIAB & ADJ_NI & $\begin{array}{c}\text { Adjusted } \\
R^{2}\end{array}$ & $N$ \\
\hline & & & & & & & \\
9.79 & 1.06 & -1.04 & -0.12 & 0.27 & 1.67 & 0.5696 & 141 \\
$(4.49)$ & $(7.98)$ & $(-7.56)$ & $(-0.16)$ & $(0.33)$ & $(4.71)$ & &
\end{tabular}

Panel B High Retained Interest / Asset

\begin{tabular}{cccccccc}
\hline Intercept & ADJ_ASSET & LIAB & SPE_ASSET & SPE_LIAB & ADJ_NI & $\begin{array}{c}\text { Adjusted } \\
R^{2}\end{array}$ & $N$ \\
\hline & & & & & & & \\
4.62 & 0.74 & -0.68 & 0.87 & -0.88 & 0.89 & 0.4700 & 141 \\
$(2.66)$ & $(5.24)$ & $(-4.62)$ & $(6.08)$ & $(-6.08)$ & $(3.46)$ & &
\end{tabular}

Notes:

ASSET is defined as data item 6 from Compustat; $L I A B$ is defined as data item 181 from Compustat; ADJ_ASSET is defined as ASSET less RET_INT and MSR; SPE_ASSET is defined as managed loans off balance sheet disclosed in the financial statements; SPE_LIAB is defined as SPE_ASSET less RET_INT and $M S R$; $N I$ is defined as data item 172 from Compustat; $A \bar{D} J \_N I$ is defined as $N I$ less gains (losses) from current year securitization activities; RET_INT is defined as retained interests from securitization transactions; MSR is defined as servicing rights from securitization activities; $M V E$ is defined as price 3 months after the year end (data item 14) multiplied by common shares outstanding 3 months after year end (data item 61). All variables are measured on a per share basis, by deflating by common shares outstanding 3 months after year end (data item 61). 


\section{Table 8}

Regulated versus Unregulated

OLS regressions of price on sponsor's assets, liabilities, net income and SPE's assets and liabilities. T-statistics are in brackets. All variables are measured per share. Observations where Rstudent is larger than 2 in absolute value have been deleted.

Model:

$M V E_{i t}=a_{0}+a_{1} A D J_{-} A S S E T_{i t}+a_{2} A D J_{-} L I A B_{i t}+a_{3} S P E_{-} A S S E T_{i t}+a_{4} S P E_{-} L I A B_{i t}+a_{5} A D J_{-} N I_{i t}+e_{i t}$

Panel A Regulated

\begin{tabular}{cccccccc}
\hline Intercept & ADJ_ASSET & LIAB & $\begin{array}{c}\text { SPE_ASSE } \\
T\end{array}$ & SPE_LIAB & ADJ_NI & $\begin{array}{c}\text { Adjusted } \\
R^{2}\end{array}$ & $N$ \\
\hline & & & & & & & \\
-0.62 & 1.80 & -1.81 & 1.71 & -1.66 & 2.90 & 0.8202 & 97 \\
$(-0.31)$ & $(7.27)$ & $(-6.94)$ & $(4.94)$ & $(-4.65)$ & $(4.53)$ & & \\
\hline
\end{tabular}

Panel B Unregulated

\begin{tabular}{cccccccc}
\hline $\begin{array}{c}\text { Intercep } \\
t\end{array}$ & $\begin{array}{c}A D J_{-} A S S \\
E T\end{array}$ & LIAB & $\begin{array}{c}S P E_{-} A S S \\
E T\end{array}$ & $S P E_{-} L I A B$ & $A D J_{-} N I$ & $\begin{array}{c}\text { Adjusted } \\
R^{2}\end{array}$ & $N$ \\
\hline & & & & & & & \\
7.69 & 0.74 & -0.63 & 0.78 & -0.79 & 0.96 & 0.4822 & 186 \\
$(4.26)$ & $(5.88)$ & $(-4.79)$ & $(5.82)$ & $(-5.73)$ & $(3.72)$ & & \\
\hline
\end{tabular}

Notes:

A sponsor firm is classified as Regulated if its primary SIC is either 6021, 6022, or 6036; all other firms are classified as Unregulated. ASSET is defined as data item 6 from Compustat; LIAB is defined as data item 181 from Compustat; $A D J \_A S S E T$ is defined as ASSET less RET_INT and MSR; SPE_ASSET is defined as managed loans off balance sheet disclosed in the financial statements; SPE_LIAB is defined as SPE_ASSET less RET_INT and MSR; $N I$ is defined as data item 172 from Compustat; $A \bar{D} J_{-} N I$ is defined as $N I$ less gains (losses) from current year securitization activities; RET_INT is defined as retained interests from securitization transactions; MSR is defined as servicing rights from securitization activities; $M V E$ defined as price 3 months after the year end (data item 14) multiplied by common shares outstanding 3 months after year end (data item 61). All variables are measured on a per share basis, by deflating by common shares outstanding 3 months after year end (data item 61). 